\title{
Commentary: The race for the second best-The no-touch saphenous vein versus the radial artery
}

\author{
Saswata Deb, MD, PhD, and Stephen E. Fremes, MD, MSc
}

\footnotetext{
From the Schulich Heart Centre, Sunnybrook Health Sciences Centre, and the Institute of Health Policy Management and Evaluation, University of Toronto, Toronto, Ontario, Canada.

Disclosures: Authors have nothing to disclose with regard to commercial support.

Received for publication Sept 26, 2019; revisions received Sept 26, 2019; accepted for publication Sept 26, 2019; available ahead of print Oct 9, 2019.

Address for reprints: Stephen E. Fremes, MD, MSc, Bernard S. Goldman Chair in Cardiovascular Surgery, Sunnybrook Health Sciences Centre, University of Toronto, 2075 Bayview Ave, Room H405, Toronto, Ontario M4N 3M5, Canada (E-mail: stephen.fremes@sunnybrook.ca).

J Thorac Cardiovasc Surg 2021;161:631-3

$0022-5223 / \$ 36.00$

Copyright (c) 2019 by The American Association for Thoracic Surgery

https://doi.org/10.1016/j.jtcvs.2019.09.130
}

Coronary artery bypass grafting $(\mathrm{CABG})$ is the indicated revascularization strategy to improve survival in patients with advanced coronary artery disease. ${ }^{1}$ The optimal grafting strategy in $\mathrm{CABG}$, however, especially with respect to the second conduit, remains controversial. ${ }^{2,3}$ In the last decade, evidence has been growing for the use of additional arterial grafting, ${ }^{4-6}$ including the radial artery (RA). ${ }^{4,5,7}$ Major societal guidelines in North America and Europe have supported the use of additional arterial grafting. ${ }^{1,8,9}$

Historically, one of the factors on which the search for alternate arterial conduits in CABG has been predicated is poor long-term saphenous vein graft (SVG) patency. ${ }^{10}$ Approximately $10 \%$ to $20 \%$ of SVG conduits fail after 1 year, and $50 \%$ fail after 10 years $^{11}$ (compared with a 10 -year patency rate of $90 \%$ for the internal thoracic artery). ${ }^{2}$ In parallel with the search for alternative arterial conduits, the surgical community have also undertaken investigations to look for measures that can improve SVG patency. One such measure is a novel method of harvesting the SVG with a no-touch technique (NT-SVG), led by Souza and colleagues ${ }^{12}$ from Sweden. Moreover, in a single-center, randomized, controlled trial (RCT) comparing NT-SVG conduits with conventionally harvested SVG conduits, this Swedish group has shown that NT-SVG conduits have superior early, ${ }^{12}$ midterm, ${ }^{13}$ and late ${ }^{14}$ patencies to conventionally harvested SVG conduits. Aggregate data, including a multicenter trial, further supports superior patency of NT-SVG conduits to conventionally harvested SVG conduits. $^{15}$ Data comparing performance of NT-SVG conduits with that of other arterial conduits (not internal thoracic arterial conduits) is scarce.

In this issue of the Journal, Dreifaldt and colleagues ${ }^{16}$ of the Swedish group report the 8-year patency results of a single-center RCT comparing the NT-SVG conduit with the RA conduit. ${ }^{16}$ Early (36 months) patency results were reported in 2013. ${ }^{17}$ More specifically, 108 patients with $P=.046)$.

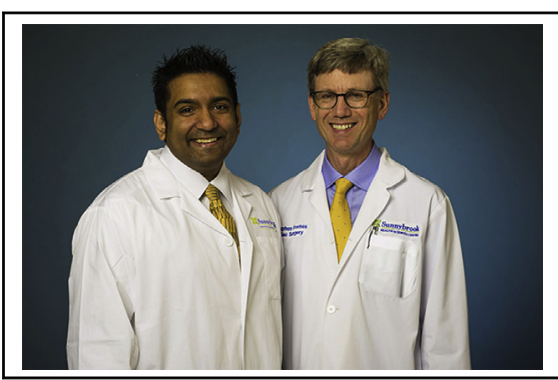

Saswata Deb, MD, PhD (leff), and Stephen E. Fremes, MD, MSc (right)

\section{Central Message}

In their single-center, randomized, controlled trial, Dreifaldt and colleagues investigated the long-term (8 years) patency of the no-touch saphenous vein graft compared with the radial artery. The findings of this study are very encouraging for the use of saphenous vein grafts, which remains one of the commonly utilized grafting conduits.

See Article page 624.

3-vessel disease undergoing CABG with 1 NT-SVG conduit and 1 RA conduit underwent randomization; within-patient randomization was performed for the study grafts to be placed to either the left or right coronary artery territory. Sequential grafting was common, and all patients received a left internal thoracic artery graft to the left anterior descending coronary artery. At 8 years, 84 of 108 patients $(78 \%)$ underwent a computed tomographic angiogram, which showed high and similar patency rates overall between the 2 conduits (NT-SVG, $86 \%$; RA, $79 \% ; P=.22$ ). In an analysis at the level of anastomoses, the NT-SVG conduit demonstrated superior patency to the RA conduit (NT-SVG, 91\%; RA, 81\%;

There are some important points to discuss about this article by Dreifaldt and colleagues. ${ }^{16}$ First, the data are very encouraging with respect to the overall high patency rate of the NT-SVG conduit at 8 years, further corroborating the limited but consistent data supporting use of the NT-SVG conduit. ${ }^{15}$ It is also postulated that arterial grafts are more resistant to atherosclerosis, ${ }^{18}$ and as such, it is encouraging that overall the patencies at 8 years were similar between the NT-SVG and the RA conduits. 
Second, this study also highlights some of the important properties that have been established about the performance of the RA as a conduit. In this trial, more than $60 \%$ of radial targets had less than $90 \%$ stenosis, with almost one-third of the RA conduits targeted to a vessel with less than $70 \%$ stenosis. Previous studies have shown that the RA has superior patency if grafted to a target vessel with a stenosis of $90 \%$ or more ${ }^{4,19}$; when targeted to vessels less than $90 \%$ stenosed, however, they are prone to spasm and eventual occlusion associated with competitive flow. ${ }^{4,19}$ In the study of Dreifaldt and colleagues, ${ }^{16}$ the patency of the NT-SVG conduits was high regardless of the severity of the target vessel stenosis, whereas a gradient in patency was observed for the RA conduits.

Another factor that may account for the lower RA patency in this study was the infrequent use of calcium-channel blockers (CCBs) in these patients ( $24 \%$ of patients received CCB therapy for hypertension). A recent meta-analysis by Gaudino and associates ${ }^{20}$ of 6 RCTs involving the RA as a conduit showed that patients receiving CCB therapy had significantly less RA occlusion at 108 months (RA occlusion with CCBs of $14.3 \%$ vs $38.9 \%$ without CCBs; adjusted Cox hazard ratio, $0.20 ; P<.001$ ), supporting the use of CCBs for at least 1 year after CABG. The same meta-analysis ${ }^{20}$ also showed that CCB therapy was protective against major adverse cardiac events (adjusted Cox hazard ratio, 0.52; $P=.02)$. The Society of Thoracic Surgeons practice guidelines state that it is reasonable to place RA grafts to targets with severe stenosis and support the use of pharmacotherapy to reduce perioperative graft spasm. ${ }^{8}$

Third, it has been shown that SVG conduits tend to have a lower patency than RA conduits in patients with diabetes. ${ }^{21}$ The proportion of patients with diabetes in the study of Dreifaldt and colleagues ${ }^{16}$ was only $19 \%$, however, compared with other studies in which there were larger cohorts of patients with diabetes $(25 \%-35 \%))^{21,22}$ As such, the results in this study may not apply to patients with diabetes.

Overall, Dreifaldt and colleagues ${ }^{16}$ are to be congratulated for undertaking this longitudinal RCT. In addition to having all the strengths of a RCT, the within-patient randomization further eliminates potential patient-level biases between the conduits, because every patient received both study conduits. The findings of this study are very encouraging for the NT-SVG technique, and relevant for the cardiac surgical community, because the SVG remains the most commonly used conduit in CABG. ${ }^{23}$ As such, additional long-term studies are required to corroborate these findings. Furthermore, one of the limitations of NT-SVG harvesting is early leg wound infections. ${ }^{15}$ To this end, given the popularity of endoscopic harvesting, future research incorporating a no-touch technique in endoscopic or other minimally invasive harvesting methods is needed.

\section{References}

1. Hillis LD, Smith PK, Anderson JL, Bittl JA, Bridges CR, Byrne JG, et al; American College of Cardiology Foundation; American Heart Association Task Force on Practice Guidelines; American Association for Thoracic Surgery; Society of Cardiovascular Anesthesiologists; Society of Thoracic Surgeons. 2011 ACCF/ AHA guideline for coronary artery bypass graft surgery. A report of the American College of Cardiology Foundation/American Heart Association task force on practice guidelines. Developed in collaboration with the American Association for Thoracic Surgery, Society of Cardiovascular Anesthesiologists, and Society of Thoracic Surgeons. J Am Coll Cardiol. 2011;58:e123-210.

2. Gaudino M, Taggart D, Suma H, Puskas JD, Crea F, Massetti M. The choice of conduits in coronary artery bypass surgery. J Am Coll Cardiol. 2015;66: 1729-37.

3. Tinica G, Chistol RO, Enache M, Leon Constantin MM, Ciocoiu M, Furnica C. Long-term graft patency after coronary artery bypass grafting: effects of morphological and pathophysiological factors. Anatol J Cardiol. 2018;20:275-82.

4. Deb S, Cohen EA, Singh SK, Une D, Laupacis A, Fremes SE, RAPS Investigators. Radial artery and saphenous vein patency more than 5 years after coronary artery bypass surgery: results from RAPS (Radial Artery Patency Study). J Am Coll Cardiol. 2012;60:28-35.

5. Benedetto U, Raja SG, Albanese A, Amrani M, Biondi-Zoccai G, Frati G. Searching for the second best graft for coronary artery bypass surgery: a network meta-analysis of randomized controlled trials. Eur J Cardiothorac Surg. 2015; 47:59-65; discussion 65 .

6. Gaudino M, Mack MJ, Taggart DP. Additional arterial conduits in coronary artery bypass surgery: finally coming of age. J Am Coll Cardiol. 2018;71:2974-6.

7. Collins P, Webb CM, Chong CF, Moat NE, Radial Artery Versus Saphenous Vein Patency (RSVP) Trial Investigators. Radial artery versus saphenous vein patency randomized trial: five-year angiographic follow-up. Circulation. 2008;117: 2859-64.

8. Aldea GS, Bakaeen F, Pal J, Fremes S, Head SJ, Sabik J, et al; Society of Thoracic Surgeons. The Society of Thoracic Surgeons clinical practice guidelines on arterial conduits for coronary artery bypass grafting. Ann Thorac Surg. 2015;101: 801-9.

9. Windecker S, Kolh P, Alfonso F, Collet JP, Cremer J, Falk V, et al. 2014 ESC/ EACTS guidelines on myocardial revascularization: the Task Force on Myocardial Revascularization of the European Society of Cardiology (ESC) and the European Association for Cardio-Thoracic Surgery (EACTS) Developed with the special contribution of the European Association of Percutaneous Cardiovascular Interventions (EAPCI). Eur Heart J. 2014;35:2541-619.

10. Desai ND, Cohen EA, Naylor CD, Fremes SE, Radial Artery Patency Study Investigators. A randomized comparison of radial-artery and saphenous-vein coronary bypass grafts. $N$ Engl J Med. 2004;351:2302-9.

11. Sabik JF III. Understanding saphenous vein graft patency. Circulation. 2011;124: 273-5.

12. Souza DS, Dashwood MR, Tsui JC, Filbey D, Bodin L, Johansson B, et al. Improved patency in vein grafts harvested with surrounding tissue: results of a randomized study using three harvesting techniques. Ann Thorac Surg. 2002; 73:1189-95.

13. Souza DS, Johansson B, Bojö L, Karlsson R, Geijer H, Filbey D, et al. Harvesting the saphenous vein with surrounding tissue for $\mathrm{CABG}$ provides long-term graft patency comparable to the left internal thoracic artery: results of a randomized longitudinal trial. J Thorac Cardiovasc Surg. 2006;132:373-8.

14. Samano N, Geijer H, Liden M, Fremes S, Bodin L, Souza D. The no-touch saphenous vein for coronary artery bypass grafting maintains a patency, after 16 years, comparable to the left internal thoracic artery: a randomized trial. J Thorac Cardiovasc Surg. 2015;150:880-8.

15. Deb S, Singh SK, de Souza D, Chu MWA, Whitlock R, Meyer SR, et al. SUPERIOR SVG: no touch saphenous harvesting to improve patency following coronary bypass grafting (a multi-centre randomized control trial, NCT01047449). J Cardiothorac Surg. 2019;14:85.

16. Dreifaldt M, Mannion JD, Hakan G, Mats L, Bodin L, Souza D. The no-touch saphenous vein is an excellent alternative conduit to the radial artery 8 years after coronary artery bypass grafting: a randomized trial. J Thorac Cardiovasc Surg. 2021;161:624-30.

17. Dreifaldt M, Mannion JD, Bodin L, Olsson H, Zagozdzon L, Souza D. The notouch saphenous vein as the preferred second conduit for coronary artery bypass grafting. Ann Thorac Surg. 2013;96:105-11.

18. Tatoulis J, Schwann TA. Long term outcomes of radial artery grafting in patients undergoing coronary artery bypass surgery. Ann Cardiothorac Surg. 2018;7: 636-43. 
19. Desai ND, Naylor CD, Kiss A, Cohen EA, Feder-Elituv R, Miwa S, et al. Impact of patient and target-vessel characteristics on arterial and venous bypass graft patency: insight from a randomized trial. Circulation. 2007;115:684-91.

20. Gaudino M, Benedetto U, Fremes SE, Hare DL, Hayward P, Moat N, et al; RADIAL Investigators. Effect of calcium-channel blocker therapy on radial artery grafts after coronary bypass surgery. J Am Coll Cardiol. 2019;73: 2299-306. Erratum in: J Am Coll Cardiol. 2019;74:597-9.

21. Deb S, Singh SK, Moussa F, Tsubota H, Une D, Kiss A, et al; Radial Artery Patency Study Investigators. The long-term impact of diabetes on graft patency after coronary artery bypass grafting surgery: a substudy of the multicenter
Radial Artery Patency Study. J Thorac Cardiovasc Surg. 2014;148:1246-53; discussion 1253.

22. Kappetein AP, Head SJ, Morice MC, Banning AP, Serruys PW, Mohr FW, et al; SYNTAX Investigators. Treatment of complex coronary artery disease in patient with diabetes: 5-year results comparing outcomes of bypass surgery and percutaneous coronary intervention in the SYNTAX trial. Eur J Cardiothorac Surg. 2013;43:1006-13.

23. Zenati MA, Bhatt DL, Bakaeen FG, Stock EM, Biswas K, Gaziano JM, et al REGROUP Trial Investigators. Randomized trial of endoscopic or open vein graft harvesting for coronary-artery bypass. N Engl J Med. 2018;380:132-41. 